\title{
A physical map of the genome of Haemophilus influenzae type b
}

\author{
Peter D. Butler* and E. Richard Moxon \\ Molecular Infectious Diseases Group, Department of Paediatrics, Institute of Molecular Medicine, University of Oxford, \\ John Radcliffe Hospital, Oxford OX3 9DU, UK
}

(Received 2 July 1990; revised 16 August 1990; accepted 24 August 1990)

\begin{abstract}
Contour-clamped homogeneous electric field pulsed-field gel electrophoresis (PFGE) was used in combination with Southern hybridization to construct a genomic restriction map for the pathogen Haemophilus influenzae serotype b, strain Eagan. Sites for four restriction endonucleases, EagI, NaeI, RsrII and SmaI, were located on the $2100 \mathrm{kbp}$ circular chromosome. Twelve potential virulence loci have been placed on the map together with certain loci essential for growth of the bacteria (e.g. ribosomal RNA operons). PFGE also provided a valuable tool for characterizing ten capsulated, type $b$ isolates (other than Eagan) known to be genetically heterogeneous and two laboratory-derived variants (transformants) derived through complex recombinational events involving random uptake of high-molecular-mass donor genomic DNA.
\end{abstract}

\section{Introduction}

Pulsed-field gel electrophoresis (PFGE) has facilitated the making of physical maps of the chromosomes of bacterial pathogens. Currently physical maps have been published for Clostridium perfringens (Canard \& Cole, 1989), Pseudomonas aeruginosa (Römling et al., 1989) and two species of the genus Haemophilus, $H$. influenzae strain Rd (Lee et al., 1989; Kauc et al., 1989) and $H$. parainfluenzae (Kauc \& Goodgal, 1989).

In the case of Haemophilus, the available physical maps concern relatively non-pathogenic strains which have been sub-cultured over many years. Encapsulated $H$. influenzae type $\mathrm{b}$ strains are a major cause of meningitis and other life-threatening infections of childhood. In this paper we report the genomic map of a representative virulent $H$. influenzae b, strain Eagan, which was isolated from the cerebrospinal fluid of a child with meningitis (Anderson et al., 1972) and indicate the positions of several of its virulence loci.

Strain Eagan was chosen because it has been well characterized in the laboratory and has been used extensively in virulence studies (Moxon \& Kroll, 1990). However, the population structure of naturally occurring isolates of capsulate $H$. influenzae is characterized by substantial diversity and comprises many genetically

\footnotetext{
Abbreviations: CHEF, contour-clamped homogeneous electric field (electrophoresis); PFGE, pulsed-field gel electrophoresis; HMT, high melting temperature; LMT, low melting temperature.
}

distinct families of strains. Each family comprises several closely related clones and, for any particular family, the clones express the identical capsular polysaccharide. Thus strains expressing any one of the six known capsular polysaccharides are represented by one or more distinct clonal clusters (families) unique to that serotype (Musser et al., 1988 b). To compare type b clones from genetically distinct clusters, including those belonging to different phylogenetic lineages, we have used PFGE to examine the restriction fragment length polymorphisms of type $b$ strains representative of the different clonal clusters to index similarities or differences in genotype.

Similarly, PFGE proved useful in the further characterization of laboratory-derived type $b$ strains which were constructed by the transformation of a capsuledeficient strain of type $d$ ancestry using donor DNA from strain Eagan.

\section{Methods}

Growth of bacteria. Liquid cultures of $H$. influenzae were grown in brain heart infusion (BHI) (Oxoid) broth supplemented with NAD (Boehringer Mannheim) $\left(2 \mu \mathrm{g} \mathrm{ml}^{-1}\right)$ and haemin (Sigma) $\left(10 \mu \mathrm{g} \mathrm{ml}^{-1}\right)$ and designated sBHI. Bacteria were also grown on solid media which consisted of BHI agar (BHI plus $1 \%$, w/v, agar) containing $10 \%(v / v)$ Levinthal base (Alexander, 1965).

Preparation of DNA. High-molecular-mass DNA was prepared from strain Eagan using phenol as described by Moxon et al. (1984); the procedure was scaled up to work from a $400 \mathrm{ml}$ culture.

To prepare chromosomal DNA in agarose blocks, BHI broth $(80 \mathrm{ml})$ 
was inoculated from a plate and growth followed to $\mathrm{OD}_{490} 0.4$ (approximately $2 \times 10^{9}$ colony-forming units $\mathrm{ml}^{-1}$ ). Chloramphenicol was added at $20 \mu \mathrm{g} \mathrm{ml}^{-1}$ and incubation was continued for $1 \mathrm{~h}$. The culture was chilled on ice for $20 \mathrm{~min}$, then bacteria were spun down at $3000 \mathrm{~g}$ at $0{ }^{\circ} \mathrm{C}$ in a Beckman JA-20 rotor and resuspended in $20 \mathrm{ml}$ (0.25 vol.) of buffer 21 (Herriott et al., 1970) chilled to $0{ }^{\circ} \mathrm{C}$.

The cells were pelleted again as described above and, finally, resuspended in $4 \mathrm{ml}(0.05 \mathrm{vol}$.) of cold buffer 21 . The cell suspension was warmed by standing for $5 \mathrm{~min}$ at room temperature. After a further $5 \mathrm{~min}$ at $37^{\circ} \mathrm{C}$ the cell suspension was mixed thoroughly with $4 \mathrm{ml}$ (equal volume) of $1.5 \%(\mathrm{w} / \mathrm{v})$ low-melting-temperature (LMT) agarose (Bethesda Research Laboratories) in buffer 21 at $37^{\circ} \mathrm{C}$.

The bacteria/agarose mixture was maintained at $37^{\circ} \mathrm{C}$ whilst volumes of $215 \mu \mathrm{l}$ were micro-pipetted into a perspex plug mould. Each space for a plug was $15 \times 5 \times 3 \mathrm{~mm}$. Plugs were allowed to solidify in moulds at room temperature for about $10 \mathrm{~min}$ then hardened at $4{ }^{\circ} \mathrm{C}$ for $15 \mathrm{~min}$ before being removed. Batches of plugs were washed in $20 \mathrm{ml}$ volumes of NDS buffer (0.5 M-EDTA, $10 \mathrm{~mm}$-Tris pH $9.5,1 \%, \mathrm{w} / \mathrm{v}$, sodium laurylsarcosine) (Schwartz \& Cantor, 1984) containing Proteinase $\mathrm{K}$ (Sigma) at $1 \mathrm{mg} \mathrm{ml}^{-1}$.After $1 \mathrm{~h}$ at room temperature, three washes of approximately $2 \mathrm{~h}, 17 \mathrm{~h}$ and $24 \mathrm{~h}$ were performed at $50^{\circ} \mathrm{C}$. Plugs were rinsed with NDS followed by five $2 \mathrm{~h}$ washes at $50^{\circ} \mathrm{C}$ to remove Proteinase $\mathrm{K}$. This procedure solubilizes everything but the DNA; the latter remains trapped in the agarose. Plugs containing DNA were then stored in NDS at $4{ }^{\circ} \mathrm{C}$ for up to 18 months. About 30 plugs were obtained from each $80 \mathrm{ml}$ culture, each plug containing about $9 \mu \mathrm{g}$ DNA.

This method was also scaled down to process $5 \mathrm{ml}$ cultures, each of which gave two plugs.

Digestion of DNA in agarose blocks. Usually digests were carried out on the DNA contained in one-third of a complete plug. Restriction enzyme buffers were diffused into the agarose blocks as outlined below. Plugs or portions of plugs were washed in Eppendorf tubes with $500 \mu \mathrm{l}$ volumes of buffer (unless stated otherwise). Fresh buffer was used for each wash. Two $30 \mathrm{~min}$ washes in TC buffer $(10 \mathrm{mM}$-Tris/ $\mathrm{HCl}, 1 \mathrm{mM}-$ cyclohexanediaminetetra-acetic acid $\mathrm{pH} 7.5$ ) containing 2 mM-PMSF (phenylmethylsulphonyl fluoride) at $0^{\circ} \mathrm{C}$ were followed by a wash in TC at $0^{\circ} \mathrm{C}$ for $30 \mathrm{~min}$. Plugs were then transferred to restriction endonuclease buffers (made according to the enzyme manufacturers' formulations) and incubated for $1 \mathrm{~h}$ at $0{ }^{\circ} \mathrm{C}$ and then for a further $1 \mathrm{~h}$ at room temperature with fresh buffer. Plugs were transferred to new Eppendorf tubes holding $75 \mu \mathrm{l}$ restriction buffer containing 2mercaptoethanol $(10 \mathrm{mM})$ and stood at room temperature for $20 \mathrm{~min}$ then incubated at $65^{\circ} \mathrm{C}$ for $15 \mathrm{~min}$ to melt the agarose. Plugs were cooled to $37^{\circ} \mathrm{C}$ for $5 \mathrm{~min}$ before the addition of the restriction enzyme and incubated at a temperature suitable for optimum enzyme activity. [The agarose remained molten at $37^{\circ} \mathrm{C}$ but not at room temperature (about $20^{\circ} \mathrm{C}$ ).] More enzyme was added over the course of about $30 \mathrm{~h}$ so that at least $20 \mathrm{U}$ of enzyme would have been added to each reaction. For Smal, as digests are incubated at $20^{\circ} \mathrm{C}$, it was necessary to melt digests at $65^{\circ} \mathrm{C}$ then cool them to $37^{\circ} \mathrm{C}$ when more enzyme was added to allow good mixing of the enzyme into the digest ( $\mathrm{SmaI}$ was usually used at about $50 \mathrm{U}$, in total, per digest because of loss of any remaining activity on repeated melting). Digests were heated at $65^{\circ} \mathrm{C}$ before storage at $4^{\circ} \mathrm{C}$ or immediately prior to loading on a gel.

Contour-clamped homogeneous electric field (CHEF) electrophoresis. Samples for electrophoresis (digests) were melted at $65^{\circ} \mathrm{C}$ for $10 \mathrm{~min}$ then micro-pipetted into the wells of the gel. $\lambda$ oligomers were made by incubating $\lambda$ DNA (New England Biolabs), $2 \mathrm{mg} \mathrm{ml}^{-1}$ in $2 \times \mathrm{SSC}, 3 \%$, $\mathrm{w} / \mathrm{v}$, Ficoll, $0.6 \mathrm{mg}$ Orange $\mathrm{G} \mathrm{ml}^{-1}$ for $30 \mathrm{~min}$ at $37^{\circ} \mathrm{C}$ then standing for $6-16 \mathrm{~h}$ at room temperature (SSC is $0.15 \mathrm{M}-\mathrm{NaCl}, 0.015 \mathrm{M}$-trisodium citrate, $\mathrm{pH} 7 \cdot 0$ ). It is essential that the $\lambda$ DNA has never been frozen to achieve good oligomerization. After loading, $\lambda$ oligomers were overlaid with about $20 \mu \mathrm{l} 1 \%(\mathrm{w} / \mathrm{v}) \mathrm{LMT}$ agarose in $0.5 \times \mathrm{TBE}$ (TBE is $0.89 \mathrm{M}$ -
Tris, $0.89 \mathrm{M}$-boric acid, $0.02 \mathrm{M}$-EDTA). Gels $(15 \times 15 \mathrm{~cm})$ were made from $1 \%$ or $1.5 \%(\mathrm{w} / \mathrm{v})$ high-melting-temperature (HMT) agarose (Sigma) or for preparative purposes $1.5 \%(\mathrm{w} / \mathrm{v})$ LMT agarose (Bethesda Research Laboratories) in $0.5 \times$ TBE. Half-concentration TBE was also used as the electrode buffer. Typically gels were run in a CHEF electrophoresis apparatus (Chu et al., 1986) with sets of electrodes separated by $27 \mathrm{~cm}$ with a potential difference of $225 \mathrm{~V}$ for $40-45 \mathrm{~h}$ at a temperature of $6^{\circ} \mathrm{C}$. Pulse times of 20 or $30 \mathrm{~s}$ proved to be optimal for the size-range of fragments being separated.

After electrophoresis, gels were stained with ethidium bromide, photographed, and the DNA transferred to a nylon filter (Hybond N, Amersham) essentially as described in the Amersham 'Membrane Transfer and Detection Methods' booklet. Ultra-violet irradation was used to attach DNA to filters.

Preparation of radioactive probes and hybridization. Nick-translation was the preferred method when purified plasmid DNA was available (Rigby et al., 1977). Plasmid DNA (500 ng to $1 \mu \mathrm{g}$ ) was used with an Amersham kit with $\left[\alpha^{-32} \mathrm{P}\right] \mathrm{dCTP}$ in quarter-scale reactions $(25 \mu \mathrm{l}$ total volume).

High-molecular-mass DNA from strain Eagan $(3 \mu \mathrm{g})$ was also used in this type of reaction to make probes to detect all bands on filters with Eagan DNA on them.

Gel-purified fragments were also a source of DNA for nicktranslation. Large fragments, $>30 \mathrm{kbp}$, were phenol-extracted from ethidium-bromide-stained bands cut from LMT agarose CHEF gels. Agarose fragments containing DNA were melted in $200 \mu 1 \mathrm{TC}$ buffer at $65^{\circ} \mathrm{C}$ for $10 \mathrm{~min}$, then extracted twice with phenol saturated with TC $(250 \mu 1)$. After two ethanol precipitations the DNA was sufficiently pure for use in a nick-translation reaction.

Small DNA fragments, $<20 \mathrm{kbp}$, from conventional agarose gels, were removed from pieces of HMT agarose using an IBI (International Biotechnologies Inc.) electroelution apparatus as described by the manufacturer. A random-primed DNA labelling kit (United States Biochemical Corporation) was then used with $\left[\alpha^{-32} \mathrm{P}\right] \mathrm{dCTP}$ to synthesize radioactive DNA (Feinberg \& Vogelstein, 1983, 1984).

Prehybridization and hybridization were carried out for $16 \mathrm{~h}$ at $37^{\circ} \mathrm{C}$ and $20 \mathrm{~h}$ at $42^{\circ} \mathrm{C}$, respectively, as described by Scott et al. (1979). Filters were then washed for three $20 \mathrm{~min}$ periods in $2 \times \mathrm{SSC}, 0.1 \%$ SDS at room temperature followed by four $30 \mathrm{~min}$ washes in $0.1 \times \mathrm{SSC}$, $0.1 \% \operatorname{SDS}$ at $37^{\circ} \mathrm{C}$ and four $5 \mathrm{~min}$ washes in $1.0 \times \mathrm{SSC}$ at room temperature. After autoradiography, filters were stripped of radioactivity for re-use as described in the Amersham booklet, except that an extra wash in $0.4 \mathrm{M}-\mathrm{NaOH}$ was included.

\section{Results and Discussion}

\section{Selection of restriction enzymes}

H. influenzae DNA has a base composition of $37 \mathrm{~mol} \%$ $\mathrm{G}+\mathrm{C}$ (Roy \& Smith, 1973); and therefore restriction enzymes with recognition sequences containing only $\mathrm{C}$ and $G$ cut the DNA less frequently than enzymes whose sites contain all four bases. It is therefore possible to calculate the theoretical frequency of endonuclease sites of any particular nucleotide sequence (Upholt, 1977). Accordingly enzymes recognizing six-base-pair sequences comprising only $\mathrm{G}-\mathrm{C}$ base pairs were used to digest $H$. influenzae DNA isolated in agarose blocks. Four such enzymes were selected which gave a manageable number of fragments (less than 25) whose size was 


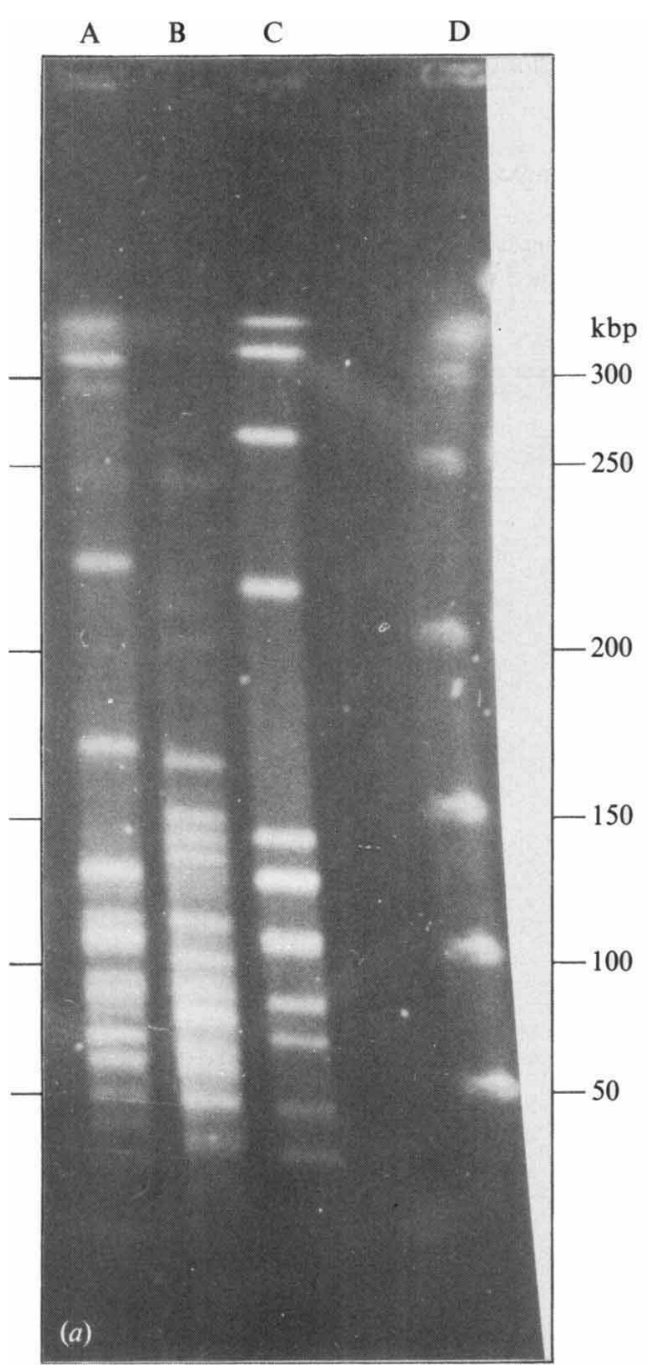

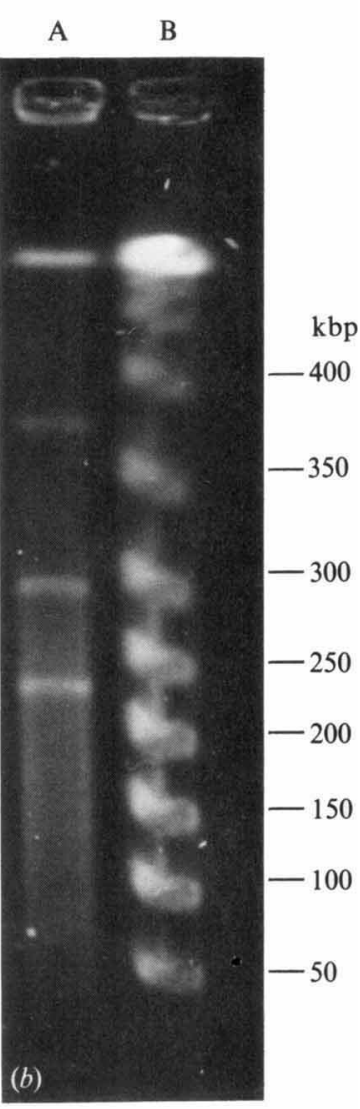

Fig. 1. CHEF gel electrophoresis of digests of $H$. influenzae strain Eagan DNA. (a) Samples of DNA, prepared in agarose blocks, were digested with EagI (A), NaeI (B) or SmaI (C) and electrophoresed for $40 \mathrm{~h}$ at $180 \mathrm{~V}(175-184 \mathrm{~mA}), 10^{\circ} \mathrm{C}$, with a pulse time of $20 \mathrm{~s}$ through a $1 \%$ HMT gel. Bacteriophage $\lambda$ DNA oligomers (total $0.6 \mu \mathrm{g}$ DNA) were used as molecular mass markers (D). Loads of digested DNA were as follows: EagI and $\mathrm{NaeI}, 30 \mu \mathrm{l}(0.6 \mu \mathrm{g})$ each; SmaI, $40 \mu \mathrm{l} ;(0.8 \mu \mathrm{g})$. The gel was photographed after staining with ethidium bromide in $0.5 \times \mathrm{TBE}$ and the background stain removed by washing in $0.5 \times$ TBE. Only the relevant part of the gel is shown. (b) DNA digested with RsrII was electrophoresed for $20 \mathrm{~h}$ at $225 \mathrm{~V}(214-230 \mathrm{~mA}), 8^{\circ} \mathrm{C}$, with a pulse time of $30 \mathrm{~s}$ through a $1 \%$ HMT gel. Approximately $0.4 \mu \mathrm{g}$ of digested DNA was loaded (lane A) together with about $0.6 \mu \mathrm{g}$ oligomerized bacteriophage $\lambda$ DNA (lane B). The gel was stained as described above. Only part of the gel is shown. larger than $20 \mathrm{kbp}$. Initially small fragments, less than $20 \mathrm{kbp}$ in size, were not considered. SmaI $\left({ }^{\prime \prime} \mathrm{CCC}^{\prime} \mathrm{GGG}^{3 \prime}\right), \quad$ EagI (C'GGCCG) and NaeI (GCC'GGC) gave reproducible results, each generating 15-23 large fragments. ApaI (GGGCC'C) gave inconsistent results and was not used. Two other enzymes with recognition sequences comprising only $\mathrm{G}-\mathrm{C}$ base pairs are SacII (CCGC'GG) and NarI (GG'CGCC); these were not useful for our mapping project. SacII generated too many fragments, more than 40 , and NarI apparently did not cleave $H$. influenzae DNA. This was demonstrated using double digests with either SmaI or RsrII; the restriction patterns obtained in the presence of $\mathrm{NarI}$ were identical to those obtained when SmaI or RsrII were used alone.

Other enzymes are commercially available which cleave recognition sites comprising more than 6 base pairs rich in $\mathrm{G}$ and $\mathrm{C}$. RsrII ( $\left.\mathrm{CG}^{\prime} \mathrm{G}_{\mathrm{T}}^{\mathrm{A} C C G}\right)$ gave only four fragments; $S f i$ (GGCCN ${ }_{4}^{\prime}$ NGGCC) did not cleave the
DNA; NotI (GC'GGCCGC) made a single cut detected by using double/sequential digests with $S m a I$ or RsrII. This single NotI site was of value in construction of the genomic map because the recognition sequence of Not I contains an EagI recognition site (C'GGCCG) and this could be located on each of the maps constructed with the different endonucleases. Thus, it was possible to align the different endonuclease maps around the Not I site. In contrast, double digests involving EagI, NaeI or Smal gave too many fragments to be of use in lining up the maps relative to one another.

\section{Analysis of digests}

Fractionation of digests was achieved using CHEF gel electrophoresis (Chu et al., 1986). Running conditions and loads were such that fragments larger than about $20 \mathrm{kbp}$ could be detected with optimal resolution. Fig. $1(a, b)$ shows typical EagI, NaeI, SmaI and RsrII digests, 
and the fragments produced with each of the four enzymes are shown in Table 1. Of these enzymes, SmaI proved to be most reproducible. Two of the bands in the SmaI digest lane (Fig. $1 a$, lane C), at about $100 \mathrm{kbp}$ and $120 \mathrm{kbp}$, stained quite brightly with ethidium bromide and suggested the presence of more than one band. In these examples, and in other cases, information gained from radioactive probing experiments was used to assess the number of DNA species in a band.

A recurring problem was the incomplete digestion of DNA. (For example, several faint bands due to this can be seen in the upper part of the NaeI track in Fig. $1 a$, lane B.) Such bands would be subject to variation between gels and they were attributed to partial digestion. However, a large EagI fragment at about $325 \mathrm{kbp}$ (the uppermost band in Fig. 1 $a$, lane A) was consistently observed. When DNA from this band was used to generate a radioactive probe, it hybridized preferentially to several smaller bands but only to a small extent to the original ( $325 \mathrm{kbp}$ ) band. Two bands, also in the EagI lane, were often visible at about 35 and $40 \mathrm{kbp}$. They were not always present and were never detected in any radioactive probing experiment.

Routinely all filters were hybridized with radioactive DNA made from strain Eagan by nick-translation. The pattern obtained was in all cases the same as that obtained with ethidium bromide staining of the original gel.

High-molecular-mass DNA, prepared by phenol extraction, was digested with EagI or NaeI to generate small fragments $(<20 \mathrm{kbp})$. These fragments were fractionated by electrophoresis through $1 \%$ HMT agarose gels run using normal (non-CHEF) conditions. After sizing these fragments, the DNA was extracted and used to prepare radioactive probes which were hybridized to CHEF gel filters containing endonucleasedigested genomic DNA from strain Eagan. This gave the sizes of these fragments and the number of types of DNA species in each band could be determined. The smallest fragment seen in SmaI digests was $36 \mathrm{kbp}$.

A digest obtained with RsrII is shown in Fig. 1(b). Although the size of the largest RsrII fragment was not measured directly from a CHEF gel, the size of the chromosome determined by summing the fragment sizes (Table 1) obtained with each of the other three enzymes was in very close agreement. Double digests of strain Eagan DNA made using RsrII and EagI or SmaI showed that there were four RsrII sites in the chromosome. When DNA from the largest RsrII fragment was used to prepare a radioactive probe the sum of the sizes of the SmaI fragments to which it hybridized was about $1400 \mathrm{kbp}$. This figure probably overestimates the size of the large RsrII fragment since the two SmaI fragments which contain RsrII sites also contain DNA from the
Table 1. Restriction fragments obtained with EagI, NaeI, RsrII or SmaI fractionated by CHEF gel electrophoresis

Multiple bands are indicated with the number of comigrating species. The total number of fragments given by each enzyme is indicated in parentheses after the sum of their sizes. The alphabetic nomenclature shown in this table is used in Figs 2 and 3.

\begin{tabular}{|c|c|c|c|c|}
\hline Enzyme & Fragment & Size & Multiplicity & $\begin{array}{c}\text { Total } \\
\text { size }(k b p)\end{array}$ \\
\hline \multirow[t]{16}{*}{ EagI } & A & 305 & & \\
\hline & B & 215 & & \\
\hline & $\mathrm{C}$ & 158 & & \\
\hline & D & 120 & 2 & \\
\hline & $\mathrm{E}$ & 105 & & \\
\hline & $F$ & 96 & 2 & \\
\hline & G & 90 & 4 & \\
\hline & $\mathrm{H}$ & 80 & 3 & \\
\hline & I & 70 & & \\
\hline & $\mathbf{J}$ & 62 & 2 & \\
\hline & $\mathrm{K}$ & 54 & & \\
\hline & $\mathrm{L}$ & 11.5 & 1 & \\
\hline & $\mathbf{M}$ & 8.5 & 2 & \\
\hline & $\mathrm{N}$ & $7 \cdot 6$ & 1 & \\
\hline & $\mathrm{O}$ & $3 \cdot 6$ & 4 & \\
\hline & $\mathbf{P}$ & $3 \cdot 3$ & 4 & $2127(31)$ \\
\hline \multirow[t]{20}{*}{ NaeI } & A & 156 & & \\
\hline & B & 140 & 2 & \\
\hline & $\mathrm{C}$ & 133 & & \\
\hline & D & 126 & 2 & \\
\hline & $\mathrm{E}$ & 120 & & \\
\hline & $\mathbf{F}$ & 108 & 2 & \\
\hline & G & 95 & & \\
\hline & $\mathrm{H}$ & 86 & & \\
\hline & I & 80 & & \\
\hline & $\mathbf{J}$ & 76 & 2 & \\
\hline & $\mathbf{K}$ & 68 & 3 & \\
\hline & L & 61 & & \\
\hline & $\mathbf{M}$ & 48 & 2 & \\
\hline & $\mathbf{N}$ & 39 & 3 & \\
\hline & $\mathrm{O}$ & $9 \cdot 6$ & 2 & \\
\hline & $\mathbf{P}$ & $7 \cdot 4$ & 1 & \\
\hline & $Q$ & $5 \cdot 7$ & 1 & \\
\hline & $\mathbf{R}$ & $5 \cdot 2$ & 2 & \\
\hline & $\mathbf{S}$ & $4 \cdot 0$ & 4 & \\
\hline & $\mathrm{T}$ & $3 \cdot 3$ & 2 & 2104 \\
\hline \multirow[t]{4}{*}{$R s r I I$} & A & $1225^{*}$ & & \\
\hline & B & 365 & & \\
\hline & C & 290 & & \\
\hline & D & 230 & & $2110 \dagger(4)$ \\
\hline \multirow[t]{11}{*}{ SmaI } & A & 330 & & \\
\hline & B & 310 & & \\
\hline & C & 270 & & \\
\hline & D & 210 & & \\
\hline & $\mathrm{E}$ & 132 & & \\
\hline & $\mathrm{F}$ & 120 & 2 & \\
\hline & G & 100 & 3 & \\
\hline & $\mathbf{H}$ & 80 & & \\
\hline & I & 70 & 2 & \\
\hline & J & 48 & & \\
\hline & $\mathbf{K}$ & 36 & & $2096(15)$ \\
\hline
\end{tabular}

* The size of the largest RsrII fragment was determined by subtraction using the average genome size obtained using the other three enzymes $(\dagger)$. 


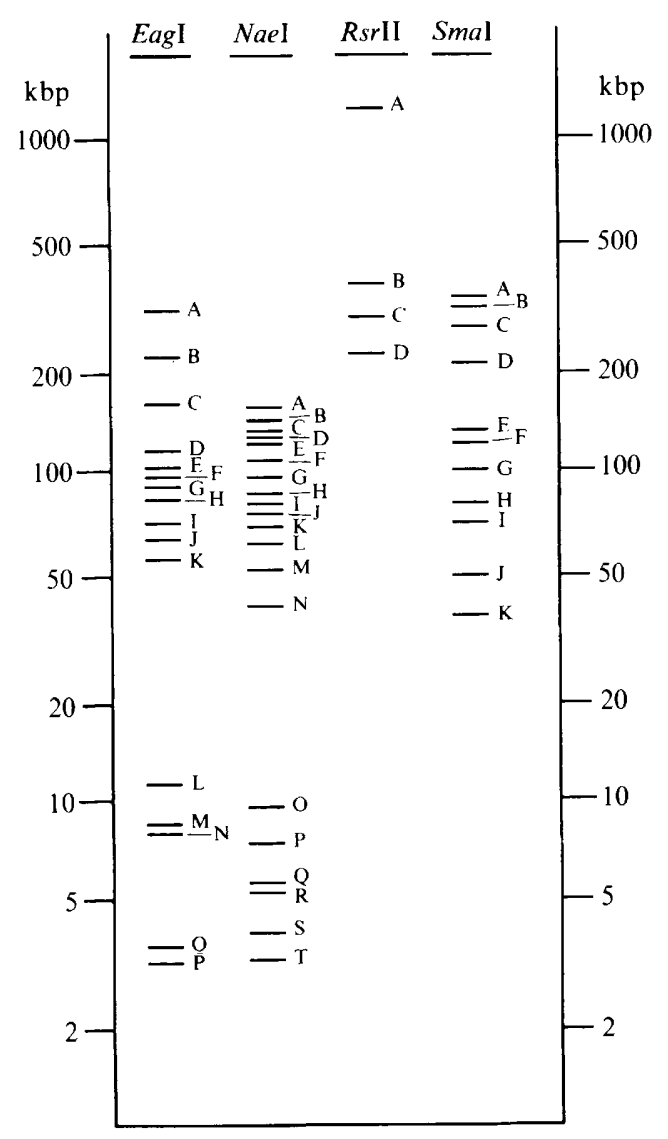

Fig. 2. Idealized fractionation of $\boldsymbol{H}$. influenzae strain Eagan DNA digested with EagI, NaeI, RsrII or SmaI. Restriction enzyme fragments listed in Table 1 were used to draw an 'idealized' agarose gel. Migration of the bands is a function of the logarithm of the size of the fragments over the complete sizing range. Bands are lettered as in Table 1. No attempt has been made to represent the multiplicity of bands stated in Table 1.

adjacent RsrII fragments. Therefore, the size of the largest RsrII fragment determined by subtraction was used. The data in Table 1 were used to generate an idealized picture of a $\mathrm{CHEF}$ gel showing all restriction fragments (Fig. 2).

The size of the $H$. influenzae strain Eagan chromosome, obtained with three restriction enzymes, was $2110 \pm 15 \mathrm{kbp}$. This is larger than the $H$. influenzae $\mathrm{Rd}$ genome, 1834-1980 kbp (Kauc et al., 1989; Lee \& Smith, 1988; Lee et al., 1989). The genomes of strains Eagan and $\mathrm{Rd}$ are relatively closely related based on metabolic enzyme typing (Musser et al., 1988a). However, comparison of the restriction fragment length polymorphisms obtained by digesting DNA from Eagan and Rd using SmaI were dissimilar (compare Fig. $1 a$, lane $\mathrm{C}$ to Fig. 5, lane C). Because strain Rd has been in laboratory use for many decades and has undergone serial passaging, we investigated the genomes of an infrequently passaged serotype d strain, RM7033, isolated from a patient with pneumonia (Kroll et al., 1989) and a nontypable strain derived from it (RM7051) using SmaI to digest the DNA (data not shown). These strains gave similar banding patterns to strain $\mathrm{Rd}$, corresponding to a chromosome size of about $1955 \mathrm{kbp}$. However, there was a clear difference between the capsulate and noncapsulate strains. A band of $209 \mathrm{kbp}$ in RM7033 decreased to $192 \mathrm{kbp}$ in RM7051, indicating that RM7033 had sustained a deletion of about $17 \mathrm{kbp}$ giving rise to the capsule-deficient strain RM7051.

\section{Ordering of fragments}

To confirm that the chromosome of $H$. influenzae is circular and to establish a framework on which to build up the remainder of the map, the relative positions of the four large RsrII fragments were determined. SmaI fragments were isolated from LMT gels and used to probe filters to which RsrII-digested DNA had been bound. Four SmaI fragments, each of which hybridized to two RsrII fragments, were found. However, the identification of these linking fragments was not as straightforward as was first hoped since two of the SmaI linking fragments were present in SmaI bands which contained more than one species (S100a, b, c and S120a, b) (see Table 1). Most of the information about the order of fragments was gained by the use of radioactive probes made from DNA prepared from LMT agarose. Bands thought to be doublets or triplets were used during the later stages of constructing the map to confirm the putative positions of these fragments. Bands of unknown size were identified by superimposing two autoradiographs, one obtained by probing endonuclease-digested genomic DNA with itself, the other obtained using a specific probe (e.g. pUO38 from the type b capsule locus). A calibration curve was constructed to determine the molecular mass of unknown bands.

Radioactive probes (listed in Table 2) of cloned Haemophilus DNA provided further information about the order of fragments and their map positions as shown in Fig. 3. The use of these probes served to confirm and expand details of the map and also indicated the relative positions of several virulence loci known or suspected to be important in pathogenicity.

\section{Ribosomal RNA operons and small restriction fragments}

Ribosomal RNA operons are the only repeated DNA sequences in most bacterial chromosomes and can give rise to various kinds of rearrangements (Smith et al., 1987). From their positions the putative location of the origin of replication can be inferred (Brewer, 1988; 


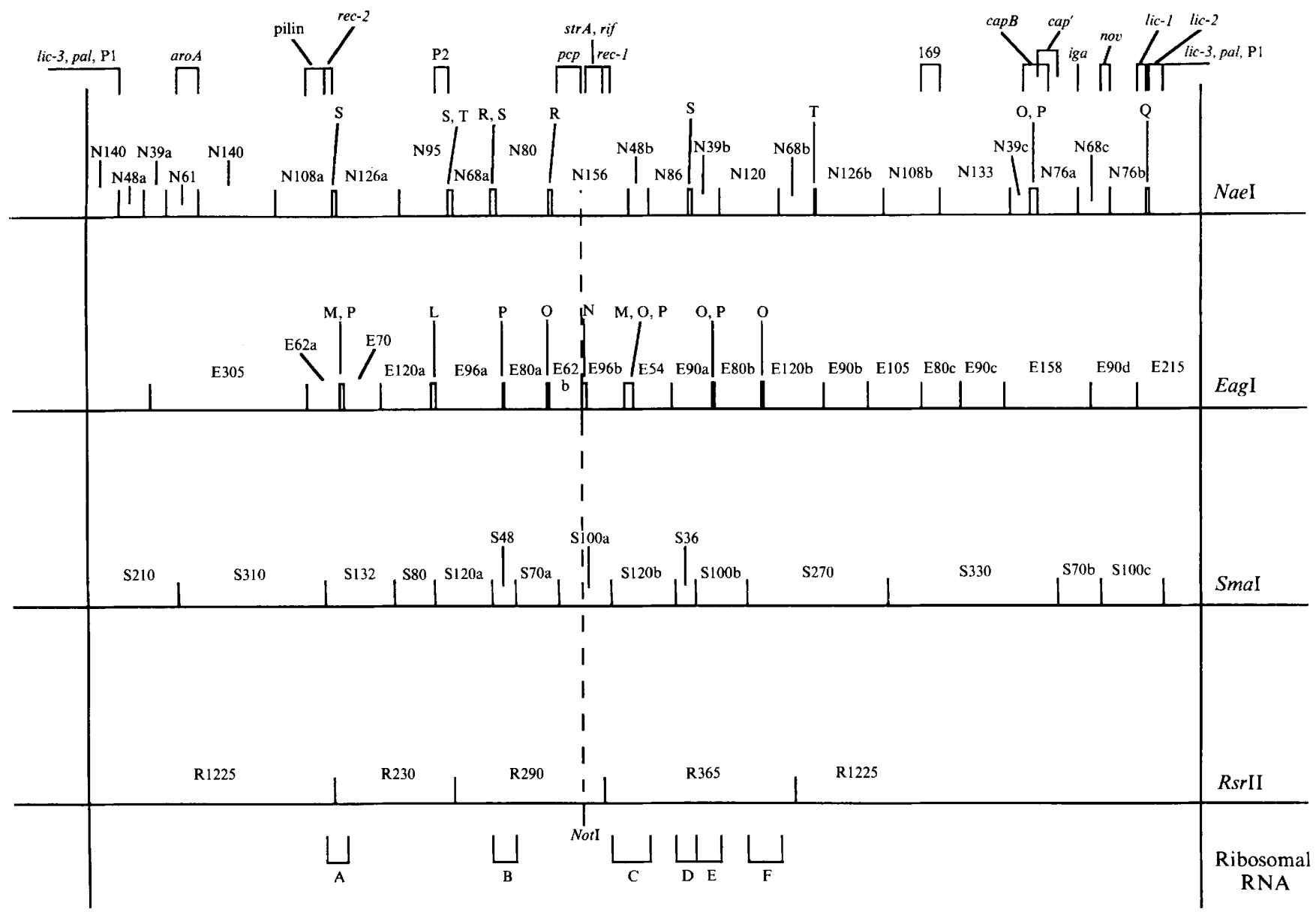

Fig. 3. Genomic map of $H$. influenzae serotype b strain Eagan. Fragments of the chromosome produced with the restriction enzymes EagI, NaeI, RsrII and SmaI which are listed in Table 1 were arranged to form the genomic map. The circular chromosome (drawn as four restriction maps) has been linearized to aid its presentation. The long vertical lines, extending through all four individual enzyme maps, indicate where the circular molecule has been 'cut'. Small EagI (L-P) and NaeI (O-T) fragments have been labelled by the alphabetic nomenclature system used in Table 1. Larger fragments are labelled with the first letter of the enzyme which gave rise to them followed by their size, e.g. S132. Bands which comigrate have been distinguished from one another by suffixing them with a lowercase letter, e.g. S100b. The single NotI site is indicated on the RsrII map. A dashed vertical line is drawn to indicate its position in the other maps. Above the maps the positions of the markers listed in Table 2 are shown. Ribosomal RNA operons are indicated beneath the RsrII map.

Nomura et al., 1984). Filters of strain Eagan DNA, digested with EagI, NaeI, RsrII or SmaI, were probed with a radioactive probe made by a random priming reaction using a $3.55 \mathrm{kbp} \mathrm{SacII}$ fragment of $H$. influenzae Rd DNA (Lee et al., 1989; kindly provided by Rosie Redfield). Only one EagI fragment ( $90 \mathrm{kbp}$ ) showed any homology to this probe, yet six were detected in both NaeI or SmaI digests and the possibility that there was homology of the ribosomal RNA probe to a series of small EagI fragments (not visible on the CHEF gel filter) was investigated. When the small EagI fragments $\mathrm{O}$ and $\mathrm{P}, 3.6 \mathrm{kbp}$ and $3.3 \mathrm{kbp}$ respectively, were mapped they coincided with regions which contained ribosomal RNA homology. An exception was the $\mathrm{S} 36(\mathrm{~K})-\mathrm{E} 90(\mathrm{Ga})$ region where there appears to be a ribosomal RNA operon but no small EagI fragment; hybridization occurred within a large EagI fragment. A very strong signal was obtained when the $36 \mathrm{kbp} S m a \mathrm{I}$ fragment was probed with the SacII ribosomal RNA probe. The $36 \mathrm{kbp}$ SmaI fragment was used as a probe so that the overlap of large fragments in this region was determined. EagI digests were fractionated on a conventional gel which was then blotted and probed with the $3.55 \mathrm{kbp}$ SacII ribosomal RNA probe. Strong homology was found to the 3.6 and $3.3 \mathrm{kbp}$ EagI fragments (fragments $\mathrm{O}$ and $\mathrm{P}$ ). Thus the positions of ribosomal RNA operons were narrowed down to the EagI O or $\mathrm{P}$ fragment (Fig. 3). The only other small fragment to show any homology to the SacII probe 
Table 2. Probes of cloned Haemophilus DNA

The plasmids listed were used/positioned on the genomic map shown in Fig. 3.

\begin{tabular}{llll}
\hline \hline Locus & \multicolumn{1}{c}{ Plasmid } & \multicolumn{1}{c}{ Source } & \multicolumn{1}{c}{ Reference } \\
\hline AroA & pHIaro & This lab.; D. Maskell & Unpublished \\
cap' & pJSK59 & This lab.; J. S. Kroll & Unpublished \\
cap b & pUO38 & This lab. & Ely et al. $(1986)$ \\
iga & pFG26 & A. Wright & Grundy et al. $(1987)$ \\
I69 & p710* & This lab. & Zwahlen et al. $(1985)$ \\
lic-1 & pC94 & This lab.; J. Weiser & Weiser et al. $(1989,1990)$ \\
lic-2 & pES2 & This lab.; J. Weiser & Weiser et al. (1989, 1990) \\
lic-3 & pL3SH6 & This lab.; D. Maskell & Weiser et al. $(1990)$ \\
nov & pnov & J. Setlow & Setlow et al. $(1984)$ \\
P1 & pRSM150 & R. Munson & Munson \& Grass (1988) \\
P2 & pRSM533 & R. Munson & Munson \& Tolan (1989) \\
P6, pal & pPX160 & R. Deich & Deich et al. (1988) \\
pcp & pPX140, (pAA140) & R. Deich & Deich et al. (1988) \\
Pilin & pSL4 & A. Wright & Langermann \& Wright (1990) \\
rec-1 & pGBRPE & G. Barcak & Barcak et al. (1989) \\
rec-2 & pDM62 & D. McCarthy & McCarthy (1989) \\
rif & pRif & W. L. Albritton $\dagger$ & Unpublished \\
str & pKLT1 & D. McCarthy & McCarthy \& Cox (1986) \\
\hline \hline
\end{tabular}

* p710 was kindly provided by Dr Alan Johnson (present address: Antibiotic Reference Laboratory, Colindale, UK).

† Department of Medical Microbiology, University of Manitoba, Winnipeg, Canada.

was the $4.0 \mathrm{kbp} \mathrm{NaeI} \mathrm{S} \mathrm{fragment.} \mathrm{The} \mathrm{EagI} \mathrm{O} \mathrm{fragment}$ (between EagI E80a and EagI E62b) does not coincide with any homology found by the $\mathrm{SacII}$ probe. Since the $\mathrm{O}$ fragment probe was made from a mixture of $3.6 \mathrm{kbp}$ fragments it is quite possible that one species is not ribosomal DNA.

Efficient replication of $E$. coli is facilitated by clustering ribosomal RNA operons around the origin of replication so that the direction of transcription follows each replication fork (Brewer, 1988). About half of the ribosomal protein genes are located in this region (Nomura et al., 1984). The gene for streptomycin resistance/sensitivity is usually part of this cluster of ribosmal protein genes, at least in those bacterial genomes which have been examined. In $H$. influenzae strain Eagan, the clustering of the ribosomal RNA genes, including at least one ribosomal protein involved in streptomycin susceptibility, suggest that the origin of replication may be located between ribosomal RNA operons B and C (Fig. 3). This concept has already been advanced by Lee et al. (1989) in proposing the possible position of the origin of replication of strain $\mathrm{Rd}$; in addition, these authors have determined the direction of transcription of the ribosomal RNA operons.

\section{Location of the capsule locus in the $H$. influenzae chromosome}

Strain Eagan has been used extensively for investigating the role of capsule as a virulence factor. The location of the cap b locus in the genomic map was determined using an $18 \mathrm{kbp}$ probe, pUO38 (Ely et al., 1986). This plasmid contains an $18 \mathrm{kbp} \mathrm{BamHI}$ fragment from cap b and has been mapped in detail using endonucleases different from those used to construct the physical map of the genome (Hoiseth et al., 1986). In order to orientate it correctly in the genome, pUO38 was digested with NaeI. Two NaeI sites were present in the BamHI fragment (Fig. 4) but further studies, including probing with the cloned $4.4 \mathrm{kbp} E c o$ RI fragment from cap b showed that the $39 \mathrm{kbp} \mathrm{NaeI}$ fragment (N39c in Fig. 3) includes the $20 \mathrm{kbp} E c o$ RI fragment at the left-hand end of cap b (Fig. 4).

\section{Transformants of $H$. influenzae $R d$}

Transformation of $H$. influenzae Rd (a capsule-deficient variant derived from a type $d$ strain) with DNA from the type b strain Eagan can produce two distinct categories of transformants (designated 01 and 02) expressing type b capsule (Zwahlen et al., 1986). These different transformants, both of which are highly virulent in experimental infections of rats, elaborate different amounts of capsular polysaccharide, that of 02 being about $50 \%$ compared to the 01 transformant. Endonuclease mapping of cap b has shown that these differences correlate with the acquisition by $\mathrm{Rd}$ of either two copies (01 transformant) or one copy (02 transformant) of capsule genes which are duplicated in the chromosome of strain Eagan. Therefore PFGE was used to characterize 


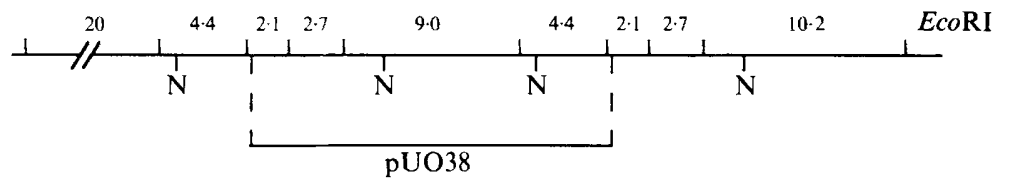

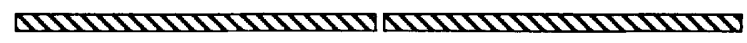

Fig. 4. Partial restriction map of the capsule locus of strain Eagan showing the EcoRI and NaeI sites. The positions of NaeI sites (N) are drawn on an EcoRI map of the capsule locus of strain Eagan. Plasmid pUO38 contains the $18 \mathrm{kbp}$ insert as indicated (Kroll \& Moxon, 1988). The extent of the tandem repeats of the $c a p$ b locus are also shown, as striped bars (Ely $e t$ al., 1986). differences in the genomes of the 01 and 02 transformants (Fig. 5).

DNA from the recipient strain and the two Rd transformants (01 and 02) (Zwahlen et al., 1983, 1985, 1986) was prepared in agarose plugs and digested with SmaI prior to fractionation by CHEF electrophoresis (Fig. 5). The recipient, strain Rd, gave a similar pattern to that observed by Lee and co-workers (Lee \& Smith, 1988; Lee et al., 1989). The 01 transformant differed in that band $\mathrm{E}$ (sized at $187 \mathrm{kbp}$ in Rd and described by Lee et al., 1989) ws found to be about $195 \mathrm{kbp}$. Both band $\mathrm{E}$ (of strain $\mathrm{Rd}$ ) and the novel, larger fragment in the 01

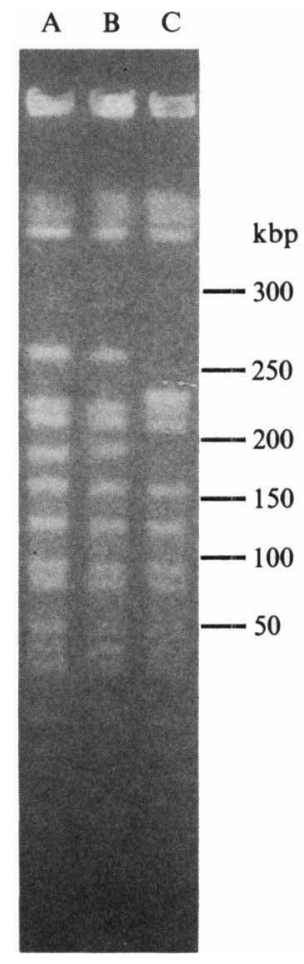

Fig. 5. CHEF gel electrophoresis of SmaI-digested DNA from transformants of $H$. influenzae Rd. DNA prepared in agarose blocks from transformant 01 (A), transformant 02 (B) and strain $\mathrm{Rd}(\mathrm{C})$ was digested with SmaI. Approximately $1 \mu \mathrm{g}$ of DNA from each digest was electrophoresed at $180 \mathrm{~V}$ with a pulse time of $20 \mathrm{~s}$ for $20 \mathrm{~h}$. Oligomers of bacteriophage $\lambda$ DNA were used as size markers (not shown). The gel was stained with ethidium bromide then washed to reduce the background staining prior to photographing. transformant hybridized to the pUO38 probe. The observed increase in the relevant SmaI fragment $(8 \mathrm{kbp})$ is less than predicted since the duplicated genes for type b capsule comprise approximately $35 \mathrm{kbp}$. The most reasonable explanation for the observed discrepancy is that approximately $27 \mathrm{kbp}$ of DNA found in the Rd genome is effectively deleted in the corresponding SmaI fragment (containing cap b) in Eagan. The recombinational event involved in the transformation would occur by a double cross-over involving regions of homology between donor and recipient so as to introduce the novel cap sequences (only a small remnant of which is found in $\mathrm{Rd}$ ) while 'looping out' a substantial amount of DNA present in the recipient $R d$ genome but absent in the donor (Eagan) strand.

Changes accounting for the $\mathbf{0 2}$ transformant are more complex. Bands B $(254 \mathrm{kbp})$ and E (187 kbp) are not present. Instead, a novel doublet of $229 \mathrm{kbp}$ which has homology to the pUO38 probe (probably in only one of the $229 \mathrm{kbp}$ species) is present. This represents a net increase of approximately $17 \mathrm{kbp}$ in the $\mathrm{Rd}$ genome, which is the increase that would be expected for the addition of a single set of type $b$ capsule genes from strain Eagan DNA. Thus, exchange of DNA involving a polymorphic SmaI site would account for the observed findings. In this case, one band increases by $17 \mathrm{kbp}$ (cap b) and a further $25 \mathrm{kbp}$ (due to the $S m a$ I polymorphism) and the contiguous SmaI fragment is decreased in size by $25 \mathrm{kbp}$; this results in a doublet of SmaI fragments each of $229 \mathrm{kbp}$.

\section{Analysis of other type b strains}

Enzyme electrotyping has shown that $H$. influenzae strains Rd and Eagan are relatively closely related (Musser et al., 1985, 1988a). However, there are no obvious similarities in the sets of restriction fragments generated by the endonuclease SmaI. Accordingly the maps obtained with this restriction enzyme ought to be dissimilar and this was found to be the case. SmaI digests of 10 serotype b strains, selected so as to be representative of the several distinct families of clones which have been described for encapsulated $H$. influenzae b strains (Musser et al., 1988a), were separated by CHEF electrophoresis. Four strains (including strain Eagan) 


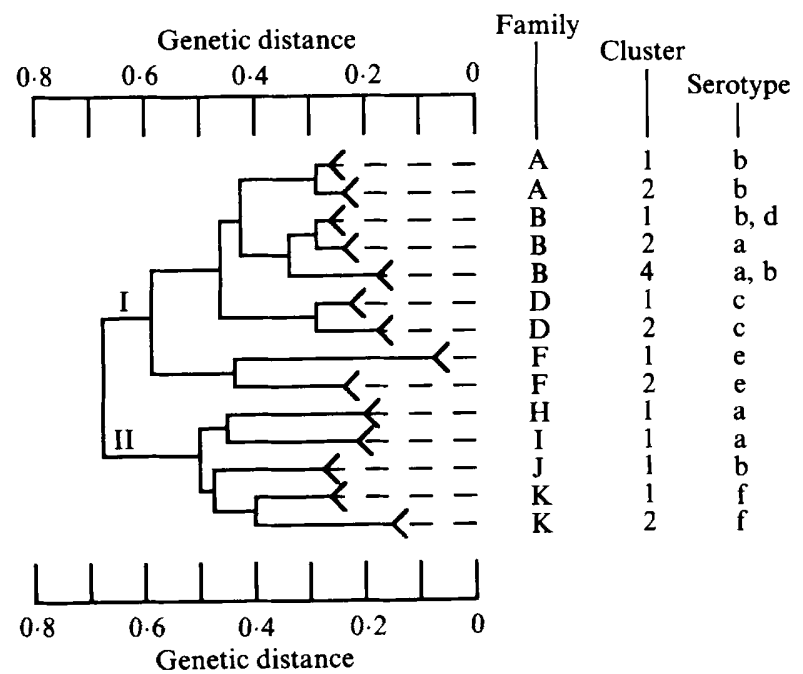

Fig. 6. Genetic relatedness of different strains of $H$. influenzae. Dendrogram showing genetic relatedness of different serotypes of capsulate $H$. influenzae based on analysis of 2209 isolates recovered from human hosts worldwide (Musser et al., 1988a). The scale for genetic distance is given at the top and bottom of the diagram, and the relatedness of any two clusters is represented by the position of the branch point joining them. Thus, strains in the cluster $F 1$ are all related within a genetic distance of 0.08 , those in cluster $B 1$ within a genetic distance of $0 \cdot 25$, while strains in these two clusters are only related to each other at a distance of 0.6. The serotypes of $H$. influenzae found in each cluster are shown on the right of the dendrogram. Data previously published (Musser et al., 1988a) and redrawn from Moxon \& Kroll (1990), Fig. 3, p. 74.

from the Al cluster (Fig. 6) gave similar patterns. A further three strains from the A2 cluster gave patterns which differed from those of the Al cluster, but were similar to one another although not to the same extent as seen in the Al cluster. Single strains from each of the B1, $\mathrm{J} 1$ and $\mathrm{J} 3$ clusters gave unique patterns quite distinct from those seen from strains from the A major lineage.

The $B$ family of clones in lineage 1 is quite diverse in terms of the serotypes represented and includes strains of serotype $a, b$ and $d$. Although serotype $b$ and d organisms are found within the $B 1$ cluster of this major lineage, no similarities were detected between SmaI digests from the type $b$ strain and those of type $d$.

We wish to thank Mr Peter Goddard for constructing the CHEF gel apparatus. Thanks are also due to Dr H. O. Smith and members of his group for providing data prior to publication and for several DNA probes used in this work. We also wish to thank Mrs Patricia Hook in helping to prepare the manuscript.

This work was supported by a MRC Programme grant (PG832535).

\section{References}

Alexander, H. E. (1965). The Haemophilus group. In Bacterial and Mycotic Infections of Man, pp. 724-741. Edited by R. J. Dubos \& J. G. Hirsch. London: Pitman Medical Publishing Co.
Anderson, P., Johnson, R. B., JR \& SMITH, D. H. (1972). Human serum activities against Haemophilus influenzae (type b). Journal of Clinical Investigation 51, 31-38.

BarCak, G. J., Tomb, J. F., LAUfer, C. S. \& SMith, H. O. (1989). Two Haemophilus influenzae $\mathrm{Rd}$ genes that complement the recA-like mutation rec-1. Journal of Bacteriology 171, 2451-2457.

BREWER, B. J. (1988). When polymerases collide: replication and the transcriptional organization of the E. coli chromosome. Cell 53, 679-686.

Canard, C. \& COLE, S. T. (1989). Genome organization of the anaerobic pathogen Clostridium perfringens. Proceedings of the National Academy of Sciences of the United States of America 86, 6676-6680.

Chu, G., Vollrath, D. \& Davis, R. W. (1986). Separation of large DNA molecules by contour-clamped homogeneous electric fields. Science 234, 1582-1585.

Deich, R. A., Metcalf, B. J., Finn, C. W., Farley, J. E. \& Green, J. E. (1988). Cloning of genes encoding a 15,000-dalton peptidoglycan-associated outer membrane lipoprotein and an antigenically related 15,000-dalton protein from Haemophilus influenzae. Journal of Bacteriology 170, 489-498.

Ely, S., TippetT, J., Kroll, J. S. \& Moxon, E. R. (1986). Mutations affecting expression and maintenance of genes encoding the serotype b capsule of Haemophilus influenzae. Journal of Bacteriology 167, 44-48.

FeinberG, A. P. \& Vogelstein, B. (1983). A technique for radiolabelling DNA restriction endonuclease fragments to high specific activity. Analytical Biochemistry 132, 6-13.

Feinberg, A. P. \& Vogelstein, B. (1984). ADDENDUM. A technique for radiolabelling DNA restriction endonuclease fragments to high specific activity. Analytical Biochemistry 137, 266-269.

Grundy, F. J., Plaut, A. \& Wright, A. (1987). Haemophilus influenzae immunoglobulin $\mathrm{A} 1$ protease genes: cloning by plasmid integration-excision, comparative analyses, and localization of secretion determinants. Journal of Bacteriology 169, 4442-4450.

Herriott, R. M., Meyer, E. M. \& Vogt, M. (1970). Defined nongrowth media for stage II development of competence in Haemophilus influenzae. Journal of Bacteriology 101, 517-524.

HoISETH, S. K., MoXon, E. R. \& SilVER, R. P. (1986). Genes involved in Haemophilus influenzae type b capsule expression are part of an 18kilobase tandem duplication. Proceedings of the National Academy of Sciences of the United States of America 83, 1106-1110.

KaUc, L. \& GoOdGal, S. H. (1989). The size and physical map of Haemophilus parainfluenzae. Gene 83, 377-380.

KaUC, L., Mitchell, M. \& GoodGal, S. H. (1989). Size and physical map of the chromosome of Haemophilus influenzae. Journal of Bacteriology 171, 2474-2479.

Kroll, J. S. \& Moxon, E. R. (1988). Capsulation and gene copy number at the cap locus of Haemophilus influenzae type b. Journal of Bacteriology 170, 859-864.

Kroll, J. S., ZAMze, S., LoYnds, B. \& Moxon, E. R. (1989). Common organization of chromosomal loci for production of different capsular polysaccharides in Haemophilus influenzae. Journal of Bacteriology 171, 3343-3347.

LANGERmanN, S. \& WRIGHT, A. (1990). Molecular analysis of the Haemophilus influenzae type b pilin gene. Molecular Microbiology 4, 221-230.

LEE, J. J. \& SMITH, H. O. (1988). Sizing of the Haemophilus influenzae Rd genome by pulsed-field agarose gel electrophoresis. Journal of Bacteriology 170, 4402-4405.

LeE, J. J., SMITH, H. O. \& Redfield, R. J. (1989). Organization of the Haemophilus influenzae Rd genome. Journal of Bacteriology 171, 3016-3024.

MCCARTHY, D. (1989). Cloning of the rec-2 locus of Haemophilus influenzae. Gene 75, 135-143.

MCCARTHY, D. \& CoX, S. S. (1986). rpe, a cis-acting element from the strA region of the Haemophilus influenzae chromosome that makes plasmid establishment independent of recombination. Journal of Bacteriology 168, 186-191.

Moxon, E. R. \& Kroll, J. S. (1990). The role of bacterial polysaccharide capsules as virulence factors. In Bacterial Capsules, pp. 65-85. Edited by K. Jann \& B. Jann. Berlin: Springer-Verlag. 
Moxon, E. R., Deich, R. A. \& Connolley, C. (1984). Cloning of chromosomal DNA from Haemophilus influenzae. Journal of Clinical Investigation 75, 298-306.

Munson, R. \& GRASS, S. (1988). Purification, cloning, and sequence of outer membrane protein P1 of Haemophilus influenzae type b. Infection and Immunity 56, 2235-2242.

Munson, R. \& Tolan, R. W. (1989). Molecular cloning, expression, and primary sequence of the outer membrane protein $P 2$ of Haemophilus infiuenzae type b. Infection and Immunity 57, 88-94.

Musser, J. M., Granoff, D. M., Pattison, P. E. \& Selander, R. K. (1985). A population genetic framework for the study of invasive diseases caused by serotype b strains of Haemophilus influenzae. Proceedings of the National Academy of Sciences of the United States of America 82, 5087-5082.

Musser, J. M., Kroll, J. S., Moxon, E. R. \& Selander, R. K. $(1988 a)$. Evolutionary genetics of the encapsulated strains of Haemophilus influenzae. Proceedings of the National Academy of Sciences of the United States of America 85, 7758-7762.

Musser, J. M., Kroll, J. S., Moxon, E. R. \& Selander, R. K. $(1988 b)$. Clonal population structure of encapsulated Haemophilus influenzae. Infection and Immunity 56, 1837-1845.

Nomura, M., Gourse, R. \& Baughman, G. (1984). Regulation of the synthesis of ribosomes and ribosomal components. Annual Review of Biochemistry 53, 75-117.

Rigby, P. W. J., DieckmanN, J. M., Rhodes, C. \& Berg, P. (1977). Labelling deoxyribonucleic acid to high specific activity in vitro by nick-translation with DNA polymerase. Journal of Molecular Biology 113, 237-251.

Römling, U., Grothues, D., Bautsch, W. \& Tummler, B. (1989). A physical map of Pseudomonas aeruginosa PAO. EMBO Journal 8, 4081-4089.

Roy, P. H. \& SMITH, H. O. (1973). DNA methylases of $H$. influenzae Rd. Journal of Molecular Biology 81, 427-444.

SCHWARTZ, D. C. \& CANTOR, C. R. (1984). Separation of yeast chromosome-sized DNAs by pulsed field gradient gel electrophoresis. Cell 37, 67-75.
Scott, A. F., Phillips, J. A., III \& Migeon, B. R. (1979). DNA restriction endonuclease analysis for localization of human $\beta$ - and $\delta$ globin genes on chromosome 11. Proceedings of the National Academy of Sciences of the United States of America 76, 4563-4565.

Setlow, J. K., Cabrera-Juarez, E. \& Griffin, K. (1984). Mechanism of acquisition of chromosomal markers by plasmids in Haemophilus influenzae. Journal of Bacteriology 160, 662-667.

Smith, C. L., ECONome, J. G., Schutt, A., KlCo, S. \& CaNtor, C. S. (1987). A physical map of the Escherichia coli K12 genome. Science 236, $1448-1453$.

UPHOLT, W. B. (1977). Estimation of DNA sequence divergence from comparison of endonuclease digests. Nucleic Acids Research 4, $1257-1265$.

WeISER, J. N., LOVE, J. M. \& Moxon, E. R. (1989). The molecular mechanism of phase variation of $\boldsymbol{H}$. influenzae lipopolysaccharide. Cell 59, 657-665.

Weiser, J. N., Maskell, D. J., Butler, P. D., Lindberg, A. A. \& Moxon, E. R. (1990). Characterization of repetitive sequences controlling phase-variation of Haemophilus influenzae lipopolysaccharide. Journal of Bacteriology 172, 3304-3309.

Zwahlen, A., Winkelstein, J. A. \& Moxon, E. R. (1983). Surface determinants of Haemophilus influenzae pathogenicity: comparative virulence of capsular transformants in normal and complementdepleted rats. Journal of Infectious Diseases 148, 385-394.

Zwahlen, A., Rubin, L. G., Connelley, C. J., Inzana, T. J. \& Moxon, E. R. (1985). Alteration of the cell wall of Haemophilus influenzae type $\mathrm{b}$ by transformation with cloned DNA: association with attenuated virulence. Journal of Infectious Diseases 152, 485-492.

ZWAHLEN, A., Rubin, L. G. \& Moxon, E. R. (1986). Contribution of lipopolysaccharide to pathogenicity of Haemophilus influenzae: comparative virulence of genetically-related strains in rats. Microbial Pathogenesis 1, 465-473. 